\title{
УДК:632.937.14+633.152 https://doi.org/10.53040/gppb7.2021.26 \\ ПОДБОР КОМПОЗИЦИИ БИОПРЕПАРАТОВ ДЛЯ ОБРАБОТКИ СЕМЯН КУКУРУЗЫ И ОПРЕДЕЛЕНИЕ ЕЕ ДЕЙСТВИЯ НА ВСХОЖЕСТЬ
}

\author{
Щербакова Т.И. \\ Институт генетики, физиологии и защиты растений, Кишинэу, Республика Молдова \\ e-mail: tatiana.scerbacova@igfpp.md
}

\begin{abstract}
Options for the two biological products composition selecting as a percentage of quantity are described. Biological products Gliocladin-SC and Trichodermin-SC based on fungi of the genus Trichoderma in a tank mixture can enhance the biological activity of the applied working solutions. In six experiments performed, 54 variants of aqueous suspensions for treating corn seeds were tested.
\end{abstract}

Key words: composition of biological products, aqueous suspension, corn.

\section{Введение}

Чрезмерное применение химических средств защиты растений, наблюдавшееся в прошлом, привело к ряду негативных последствий: сокращению биоразнообразия, снижению биологической продуктивности сельскохозяйственных культур, нарушению функционирования почвенных микробиоценозов, снижению пищевой ценности выращенной продукции. Для природных экосистем опасность представляет высокая устойчивость пестицидов к распаду, в результате чего происходит их миграция по профилю почвы, переход в атмосферный воздух с испарениями или с пылью, через растения в организмы потребителей. Устойчивое ухудшение свойств агроэкосистем и почвы, как среды обитания полезной биоты, продолжается [1].

Другая проблема применения пестицидов - стремительное развитие фунгицидной сопротивляемости вредными организмами. При частом использовании одного фунгицида большинство целевых патогенов могут вырабатывать устойчивость в течение одного вегетационного периода. Вследствие этого появляются новые расы патогенных агентов, возрастает их агрессивность, расширяется специализация [2].

Альтернативой использования пестицидов является внедрение в систему интегрированной защиты биологических препаратов на основе живых микроорганизмов и наиболее часто применяемыми из них являются биофунгициды на основе грибов рода Trichoderma Pers. ex Fr. В последние годы приоритетным направлением биозащиты растений становится создание и использование смесевых комплексных биосредств, повышающих биологическую эффективность, расширяющих спектр действия и полифункциональность. Поэтому целью исследований являлось подобрать композицию двух биопрепаратов на основе грибов Trichoderma для предпосевной обработки семян кукурузы и определить ее действие на всхожесть.

\section{Материалы и методы}

Исследования проводили в лабораторных условиях. Для повышения эффективности применения биопрепаратов в защите семян и проростков кукурузы от корневых гнилей, исследовали действие композиций двух биопрепаратов на основе Trichoderma на всхожесть методом предпосевной обработки семян. В смесях использовали разработанные нами грибные биопрепараты GliocladinăSC и Trichodermină-SC с действующим началом грибов Trichoderma virens Miller, Giddens and Foster, штамм 3X и T.viride Pers. штамм M-10, соответственно. Биопрепараты внесены в Государственный реестр средств фитосанитарного назначения Республики Молдова для предпосевной обработки семян. Материалом служили семена сахарной кукурузы гибрида Porumbeni-280.

Для создания композиции провели 6 опытов, в которых использовали разные процентные соотношения исходной концентрации биопрепаратов: 1) $20 \%$ Gliocladină-SC $+80 \%$ TrichoderminăSC; 2) $30 \%$ Gliocladină-SC + 70\% Trichodermină-SC; 3) 40\% Gliocladină-SC $+60 \%$ TrichoderminăSC; 4) $60 \%$ Gliocladină-SC + 40\% Trichodermină-SC; 5) 70\% Gliocladină-SC + 30\% TrichoderminăSC; 6) $80 \%$ Gliocladină-SC + 20\% Trichodermină-SC.

В каждом опыте из баковой смеси биопрепаратов готовили 9 концентраций водных суспензий, ими обрабатывали семена. Варианты концентраций: 1) 2,5\%; 2) 5,0\%;3) 10,0\%; 4) 20,0\%; 5) $30,0 \%$; 6) $50,0 \%$; 7) 70,0\%; 8) 80,0\%; 9) 100\%; 10) контроль -обработка водой. Всего было испытано 54 варианта водных суспензий.

Обработанные семена проращивали в кюветах в стерильном субстрате (чернозем $+10 \%$ 
песка) в трехкратной повторности. Через 7 дней определяли действие баковой смеси в указанных концентрациях измерением биометрических показателей проростков, учитывали энергию прорастания, всхожесть, длину ростка и корня, массу 100 ростков.

В каждом из 6 опытов отобрали вариант с лучшими показателями и провели еще один эксперимент в нестерильном субстрате.

\section{Результаты и обсуждение}

Использование в баковой смеси биопрепарата Gliocladină-SC основывается на широком спектре фунгицидного действия. Ранее, в наших исследованиях было определено 18 агентов-возбудителей болезней растений, проявляющих чувствительность к этому препарату. К их числу относятся грибы Fusarium, возбудители фузариозных гнилей - Fusarium oxysporum Schl., F.culmorum Sacc, F.graminearum Shwabe., F.verticillioides (Sacc.) Nirenberg, F.solani Ap. et Woll, F.sporotrichioides Sherb., F.gibbosum App. et Woll.; Botrytis cinerea Pers., Sclerotinia sclerotiorum (Lib) de Bary, Rhizoctonia solani Kuhn., Thielaviopsis basicola Ferr., Monilia cinerea Bonod., M.fructigena (Pers.) Pers. и др. [3].

Механизм действия биопрепарата состоит как в непосредственном действии живого микроорганизма на возбудителей болезней (микопаразитизм, колонизация патогенных структур), так и в действии метаболитов, выделяемых продуцентом в жидкую питательную среду в процессе культивирования (подавление роста патогена, лизис клеточных оболочек, нейтрализация токсинов) [4].

Биопрепарат Trichodermină-SC, кроме антифунгального действия на многие патогены, оказывает более выраженный стимулирующий эффект как на прорастающие семена при обработках до посева, так и при обработках по вегетации.

При проведении экспериментов в каждом из 6-ти опытов отмечена концентрация с лучшими показателями, по сравнению с контролем опыта (табл. 1).

Таблица 1. Влияние композиций биопрепаратов Gliocladină-SC + Trichodermină-SC на биометрические показатели проростков сахарной кукурузы гибрида Porumbeni-280 при обработке семян до посева в стерильном субстрате

\begin{tabular}{|c|c|c|c|c|c|}
\hline $\begin{array}{c}\text { Вариант, концентрация } \\
\text { водной суспензии, \% }\end{array}$ & $\begin{array}{l}\text { Энергия про- } \\
\text { растания, \% }\end{array}$ & $\begin{array}{c}\text { Всхожесть, } \\
\%\end{array}$ & $\begin{array}{c}\text { Длина } \\
\text { ростка, см }\end{array}$ & $\begin{array}{c}\text { Длина корня, } \\
\text { см }\end{array}$ & $\begin{array}{l}\text { Масса } 100 \\
\text { ростков, Г }\end{array}$ \\
\hline \multicolumn{6}{|c|}{ Опыт 1, Gliocladină-SC 20\% + Trichodermină-SC $80 \%$} \\
\hline 30,0 & 89 & 96 & 14,8 & 12,1 & 46,43 \\
\hline контроль & 76 & 95 & 13,3 & 10,9 & 41,34 \\
\hline \multicolumn{6}{|c|}{ Oпыт 2, Gliocladină-SC 30\% + Trichodermină-SC 70\% } \\
\hline 5,0 & 98 & 98 & 14,7 & 16,5 & 49,13 \\
\hline контроль & 94 & 98 & 13,1 & 14,1 & 41,94 \\
\hline \multicolumn{6}{|c|}{ Опыт 3, Gliocladină-SC 40\% + Trichodermină-SC 60\% } \\
\hline 30,0 & 100 & 100 & 16,4 & 15,2 & 51,87 \\
\hline контроль & 97,3 & 98,7 & 14,6 & 13,8 & 46,27 \\
\hline \multicolumn{6}{|c|}{ Опыт 4, Gliocladină-SC 60\% + Trichodermină-SC $40 \%$} \\
\hline 20,0 & 96 & 100 & 14,4 & 15,8 & 46,53 \\
\hline контроль & 97,3 & 100 & 13,9 & 14,5 & 45,01 \\
\hline \multicolumn{6}{|c|}{ Oпыт 5, Gliocladină-SC 70\% + Trichodermină-SC 30\% } \\
\hline 30,0 & 97,3 & 100 & 19,6 & 16,7 & 61,13 \\
\hline контроль & 93,3 & 100 & 18,4 & 14,3 & 57,76 \\
\hline \multicolumn{6}{|c|}{ Опыт 6, Gliocladină-SC $80 \%$ + Trichodermină-SC $20 \%$} \\
\hline 30,0 & 96,0 & 100 & 17,4 & 17,4 & 58,05 \\
\hline контроль & 94,7 & 98,7 & 16,0 & 15,8 & 52,06 \\
\hline
\end{tabular}

В опыте 1 в композиции, состоящей из Gliocladină-SC 20\% + Trichodermină-SC 80\%, лучшей отмечена 30\%-я водная суспензия, при обработке семян перед посевом энергия прорастания составила $89 \%$, всхожесть - 96\%, длина ростка была больше контроля на $11,3 \%$, длина корня - на $11,0 \%$, масса 100 ростков - на $12,3 \%$.

B опыте 2 при использовании композиции Gliocladină-SC 30\% + Trichodermină-SC 70\%, лучшие результаты получены при обработке семян 5,0\%-й концентрацией, при которой энергия прорастания и всхожесть составили 98\%, длина ростка превышала контроль на $12,2 \%$, длина корня 
на $17,0 \%$, масса 100 ростков - на $17,1 \%$.

B опыте 3 в композиции Gliocladină-SC $40 \%$ + Trichodermină-SC $60 \%$ отмечена 30\% я концентрация, при которой энергия прорастания и всхожесть составили $100 \%$, длина ростка больше контроля на $12,3 \%$, длина корня на $10,1 \%$, масса 100 ростков - на $12,1 \%$.

В опыте 4 в смеси Gliocladină-SC $60 \%$ + Trichodermină-SC 40\% отмечена 20\%-я водная суспензия. Энергия прорастания составила 96,0\%, всхожесть - 100\%, длина ростка превышала контроль на 3,6\%, длина корня на 9,0\%, масса 100 ростков - на 3,4\%.

В опыте 5, Gliocladină-SC 70\% + Trichodermină-SC 30\% лучшие результаты отмечены в концентрации $30 \%$, всхожесть составила $100 \%$, длина ростка больше контроля на $6,5 \%$, длина корня на $16,8 \%$, масса 100 ростков на $5,8 \%$.

B опыте 6, Gliocladină-SC 80\% + Trichodermină-SC 20\%, при обработке семян 30\%-й водной суспензией, отмечено увеличение длины ростка на 8,8\%, длины корня на 10,1\%, массы 100 ростков на $11,5 \%$ по сравнению с контролем.

Из лучших вариантов провели еще один эксперимент в нестерильном субстрате (табл. 2).

Таблица 2. Влияние композиций биопрепаратов Gliocladină-SC + Trichodermină-SC на биометрические показатели проростков сахарной кукурузы гибрида Porumbeni-280 при обработке семян до посева в нестерильном субстрате

\begin{tabular}{|c|l|c|c|c|c|c|}
\hline $\begin{array}{c}\text { № } \\
\text { опыта }\end{array}$ & $\begin{array}{c}\text { Вариант, концентрация } \\
\text { водной суспензии }\end{array}$ & $\begin{array}{c}\text { Энергия } \\
\text { прорастания, \% }\end{array}$ & $\begin{array}{c}\text { Всхожесть, } \\
\%\end{array}$ & $\begin{array}{c}\text { Длина } \\
\text { ростка, см }\end{array}$ & $\begin{array}{c}\text { Длина } \\
\text { корня, см }\end{array}$ & $\begin{array}{c}\text { Масса 100 } \\
\text { ростков, г }\end{array}$ \\
\hline 1 & Gl 20\%+Tr 80\%, 30\% & 88 & 93 & 18,8 & 17,1 & 68,7 \\
\hline 2 & Gl 30\%+Tr 70\%, 5\% & 91 & 95 & 19,0 & 17,2 & 67,7 \\
\hline 3 & Gl 40\%+Tr 60\%, 30\% & 100 & 100 & 19,8 & 18,6 & 70,7 \\
\hline 4 & Gl 60\%+Tr 40\%, 20\% & 97 & 100 & 18,6 & 17,4 & 66,0 \\
\hline 5 & Gl 70\%+Tr 30\%, 30\% & 95 & 97 & 19,3 & 18,2 & 69,8 \\
\hline 6 & Gl 80\%+Tr 20\%, 30\% & 96 & 97 & 19,2 & 18,4 & 69,3 \\
\hline & Контроль & 83 & 92 & 17,4 & 16,4 & 62,7 \\
\hline & $\mathrm{HCP}_{0.05}$ & 12 & 5 & 1,5 & 1,7 & 6,1 \\
\hline
\end{tabular}

Примечание: Gl - Gliocladină-SC, Tr - Trichodermină-SC

По результатам эксперимента в нестерильном субстрате максимальные биометрические показатели проростков отмечены в композиции Gliocladină-SC 40\% + Trichodermină-SC 60\%, 30\%-я водная суспензия (опыт 3), при которой энергия прорастания и всхожесть составили 100\%, длина ростка была больше контроля на 13,8\%, длина корня на 13,4\%, масса 100 ростков на 12,7\%. Композицию биопрепаратов можно использовать для предпосевной обработки семян сахарной кукурузы.

\section{Выводы}

Из проведенных исследований следует, что для защиты сахарной кукурузы гибрида Porumbeni280 от корневых и стеблевых гнилей и получения дружных всходов, можно проводить предпосевную обработку семян композицией биопрепаратов Gliocladină-SC 40\% + Trichodermină-SC 60\%, 30\%-й водной суспензией, или в количественном соотношении для обработки 1 тонны семян потребуется 1,2 л биопрепарата Gliocladină-SC + 1,8 л биопрепарата Trichodermină-SC + 7 л воды.

Работа выполнена при финансовой поддержке проекта Государственной программы № 20.80009.7007.16 „Sinergismul dintre factorii naturali şi mijloacele microbiologice, ecologic inofensive, de reglare a densităţii populaţiilor de organisme dăunătoare pentru protecţia culturilor agricole în agricultura convenţională şi ecologică”, финансируемой Национальным Агентством по Исследованиям и Развитию Республики Молдова.

\section{Литература}

1. РОГОЗИН, М.Ю., БЕКЕТОВА, Е.А. Экологические последствия применения пестицидов в сельском хозяйстве. Молодой ученый, 2018, nr. 25(211), с. 39-43. Электронный pecypc. URL: https://moluch.ru/archive/211/-51593/ - дата обращения 15.08.2021.

2. МОРОЗОВ, Д.О., КОРШУНОВ, С.А., ЛЮБОВЕДСКАЯ, А.А. и др. Современные системы интегрированной защиты сельскохозяйственных растений. М.: ФГБНУ «Росинформагротех», 2019, 92 с.

3. ЩЕРБАКОВА, Т.И. Спектр антифунгального действия биопрепарата на основе Trichoderma virens Miller, Giddens and Foster на патогены сельскохозяйственных культур. J. Știința agricolă, 2019, nr. 1, p. 84-88.

4. HARMAN, G.E. Multifunctional fungal plant symbionts: new tools to enhance plant growth and productivity. New Phytologist, 2011, v. 189, nr. 3, p. 647-649. 